\title{
SIKAP OPTIMIS DIMASA PANDEMI COVID-19
}

\author{
Partono $^{1)}$, Amrina Rosada ${ }^{2)}$ \\ IAIN KUDUS \\ E-mail: partono@iainkudus.ac.id ${ }^{1)}$, amrinarosyada5411@ gmail.com $^{2)}$
}

\begin{abstract}
ABSTRAK
Tujuan penelitian adalah guna mengetahui bagaimana masyarakat menyikapi masa pandemi Covid-19 ini dengan tenang dan tidak gegabah. Fokus masalah penelitian ini adalah tentang bagaimana peran masyarakat menerapkan sikap optimis dimasa pandemi Covid-19 ini. Jenis penelitian ini merupakan pendekatan kualitatif. Jenis penelitian kepustakaan dengan menggunakan pendekatan kualitatif deskriptif. Hasil penelitian ini menunjukkan bahwa perilaku optimis yang ditampilkan oleh masyarakat sangat penting, sehingga harus ditingkatkan. Untuk meyadarkan masyarakat bahwa optimis adalah kunci imun menjadi kuat. Hal ini bertujuan agar masyarakat Indonesia sama-sama berikap positif untuk hadapi Covid-19. Sikap optimis akan meningkatkan imunitas tubuh sehingga kemungkinan terkena virus corona akan rendah. Sikap optimis akan menjaga dan meningkatkan imunitas semakin naik. Namun, jika stress maka akan berpengaruh juga pada imunitas. Sehingga demikian masyarakat diminta untuk menjaga pola pikir yang positif salah satunya yakni optimis dan peduli atau tidak egois, serta mengikuti anjuran pemerintah seperti sosial distancing, menghindari keramaian, bekerja dari rumah, beribadah dirumah dan himbauan dari pemerintah lainnya.
\end{abstract}

Kata Kunci: Sikap Optimis, Masa Pandemi, Covid-19 


\section{ABSTRACT}

The purpose of this research is to find out how people respond to the Covid19 pandemic period calmly and not rashly. The focus of this research problem is on how the community's role in implementing an optimistic attitude during the Covid-19 pandemic. This type of research is a qualitative approach. This type of library research uses a descriptive qualitative approach. The results of this study indicate that optimistic behavior displayed by the community is very important, so it must be improved. To make people aware that optimism is the key to being strong immune. It is intended that Indonesian people are equally positive to face Covid-19. An optimistic attitude will increase body immunity so the possibility of corona virus will be low. An optimistic attitude will maintain and enhance immunity. However, if stressed, it will also affect immunity. So that the community is asked to maintain a positive mindset one of which is optimistic and caring or unselfish, as well as following the government's recommendations such as social distancing, avoiding crowds, working from home, worshiping at home and appeals from other governments.

Keywords: Optimistic Attitude, Pandemic Period, Covid-19

\section{A. PENDAHULUAN}

Saat ini dunia sedang dihebohkan dengan adanya misteri Covid-19 yang menjadi musuh terbesar dunia saat ini. Hampir semua negara ikut aktif terlibat dalam memeranginya. Covid-19 adalah musibah dunia, ratusan ribu manusia terinfeksi dan ribuan lainnya meninggal dunia. Dengan jumlah kasus Covid-19 yang meningkat setiap harinya, tentu hal ini menjadi hal yang sangat mencemaskan bagi sebagian besar masyarakat. Pada tanggal 30 Januari 2020 Organisasi Kesehatan Dunia (WHO) menyatakan bahwa virus corona sebagai situasi darurat global atau public health emergency of international concern (PHEIC). Peristiwa yang dimaksud adalah fenomena yang beresiko mengancam kesehatan masyarakat negara lain mengenai penularan penyakit lintas batas negara sehingga membutuhkan tanggapan International yang terkoordinasi. Perlu kita ketahui secara singkat yakni corona virus adalah sekumpulan virus dari subfamily Orthocoronavirinae dalam keluarga 
Coronaviridae dan Ordo Nidovirales. Kelompok virus ini yang dapat menyebabkan penyakit pada burung dan mamalia. ${ }^{1}$

Penduduk Indonesia adalah, penduduk terbanyak dibelakang China, India, dan Amerika Serikat. Dari sisi kedisiplinan harus diakui bahwa kesadaran masyarakat Indonesia masih sangat rendah, sementara dari sisi kekuatan ekonomi Indonesia juga tidak bisa dibilang kuat. Berbagai faktor ini akan menjadi kendala besar dimana opsi seperti lockdown yang dilakukan oleh berbagai negara tidak akan berjalan baik diIndonesia. Jika lockdown diberlakukan akan terjadi banyak sekali ketidakstabilan, baik dari sisi moral dan sosial. Masyarakat dan para pekerja yang berpenghasilan menengah kebawah akan merasa keberatan dan sangat terpukul jika lockdown diberlakukan. Dampak adanya virus ini pun sangat berat yakni fisik yaitu efek dari virus itu sendiri, psikis/mental dari pemberitaan atau kabar yang beredar, dan yang paling miris yaitu ekonomi.

Sejauh ini banyak pemikiran yang diajukan sebagai upaya untuk melawan pandemi Covid-19 di Indonesia, lockdown total, lockdown sebagian, pengobatan, pencegahan, dan lain sebagainya. Harus disiapkan dampak pada masyarakat yang tidak bisa dikendalikan fikiran gelapnya, yang pada saat ada himbauan untuk tidak keluar rumah dan harus dirumah saja, mendengarkan tangisan demi tangisan anak yang kelaparan. Dulu jumlahnya masih bisa terukur, namun di masa Covid-19 ini jumlahnya meledak, dan dalam beberapa bulan ke depan, makin tidak bisa diprediksi. Dampak paling mematikan adalah mereka yang tidak punya imunitas yang kuat. Dengan sikap yang takut akan segala ancaman dan keresahan, akal akan mengeluarkan hormon stress dan mematikan imunitas tubuh atau bisa disebut Shutdown the Immune System, yang pada akhirnya tidak bisa melawan virus corona. Karenanya, ditengah kegalauan menghadapi Covid-19 di Negeri ini selain berbagai upaya yang tengah ditempuh pemerintah dalam menghadang pandemi Covid19 ini ada energi besar yang dapat dibangun. Namun tak banyak disadari oleh masyarakat Indonesia yakni sikap optimis dalam menghadapi pandemi Covid-19 ini. Layaknya Covid-19 yang mudah tersebar, sikap optimis juga harus mudah tersebar dan merasuki jiwa-jiwa anak bangsa,

${ }^{1}$ M Alief Ibadurrahman, Corona Virus, (Bekasi: MAI, 2020), hlm. 13 
hingga tumbuh keyakinan kuat untuk bisa berdiri tegak menghadapi pandemi Covid-19.

Optimis mempunyai andil yang besar untuk melenyapkan serangan Covid-19 disamping menjaga imunitas tubuh dan pola makan yang sehat. Perlu kita ketahui pengertian optimis menurut Kamus Besar Bahasa Indonesia adalah orang yang selalu berpengharapan baik atau perpandangan positif dalam melakukan segala hal. Optimis adalah sesuatu yang terlintas didalam hati yang merupakan harapan pandangan yang positif, ketenangan hati yang diyakini dimasa yang akan datang akan baik. ${ }^{2}$ Sikap optimis akan meningkatkan imunitas tubuh sehingga kemungkinan terkena virus corona akan rendah. Sikap optimis akan menjaga dan meningkatkan imunitas semakin naik. Namun, jika stress maka akan berpengaruh juga pada imunitas. Sehingga demikian masyarakat diminta untuk menjaga pola pikir yang positif salah satunya yakni optimis dan peduli atau tidak egois. Namun tentu saja hal ini harus diimbangi pula dengan mengikuti anjuran pemerintah seperti sosial distancing, menghindari keramaian, bekerja dari rumah, beribadah dirumah dan himbauan dari pemerintah lainnya.

Jadi melihat dari paparan tersebut melahirkan pertanyaan bagaimana masyarakat Indonesia menerapkan sikap optimis dalam menghadapi pandemi covid-19 ini. Jenis penggolongan penelitian ini adalah penelitian kualitatif deskriptif.

\section{B. PEMBAHASAN}

\section{Sikap optimis}

Menurut Kamus Besar Bahasa Indonesia (KBBI) optimis adalah orang yang selalu berpengharapan baik dan berpandangan positif dalam menghadapi segala hal. Optimis adalah sesuatu yang terlintas didalam hati yang merupakan harapan pandangan yang positif, ketenangan hati, bijaksana dan juga berarti semua aktivitas kebaikan yang diyakini bahwa dimasa yang akan datang akan lebih baik.

Winston Churchill mengatakan optimis adalah selalu melihat kesempatan dalam masalah. Orang yang optimis akan melihat sisi baik setiap orang dalam keadaan sulit sekalipun, ia bisa melihat

${ }^{2}$ Mastuti et al, Teaching from Home, (Jakarta: Yayasan Kita Menulis, 2020), hlm. 79 
peluang dan kesempatan. Orang yang optimis akan selalu berpikir positif kepada diri sendiri juga kepada orang lain. ${ }^{3}$

Menurut Susan Robinson Whelen mengemukakan bahwa kesehatan mental yang paling utama adalah memiliki sikap positif dan optimis. Sikap optimis sangat mempengaruhi kesehatan fisik seseorang. Berpikir postif akan meningkatkan sistem imun, sebaliknya berpikir negatif akan melemahkan sistem imun. ${ }^{4}$

Menurut Ibrahim Elfiky mengakatan berpikir positif merupakan sumber kekuatan. Berpikir positif merupakan sumber kekuatan karena ia membantu memikirkan solusi sampai mendapatkannya. Dengan begitu seseorang akan bertambah mahir, percaya, dan kuat. Berpikir positif disebut sumber kebebasan karena dengan bersikap positif seseorang akan terbebas dari penderitaan dan tuntutan pikiran negatif serta pengaruhnya pada fisik. ${ }^{5}$

Menurut Brissette sesuai dengan penelitian yang telah dilakukan optimisme dapat dibentuk dengan keinginan dan dukungan. Optimisme dapat dikondisikan oleh diri sendiri dan kelompok orang yang saling mendukung. Optimisme juga dipengaruhi oleh kondisi yang ada pada diri individu yaitu melalui penerimaan diri. ${ }^{6}$

Sikap optimis adalah mengarahkan pikiran kepada hal-hal positif sehingga mendorong semangat untuk meraih hasil yang baik, dan tidak termenung meratapi nasib. Mengucapkan perkataan yang baik adalah kegiatan yang hanya lahir dari cara berpikir yang baik. Cara berpikir yang baik menggambarkan sikap mental yang positif. Sikap

${ }^{3}$ Wahyudi I, Rahasia Menjadi Kaya Sejak Dini, (Jakarta: Elex Media Komputindo, 2011), hlm. 20

${ }^{4}$ Ide P, Imunisasi Mental untuk Bangkitkan Optimisme, (Jakarta: Elex Komputindo, 2010), hlm 205

${ }^{5}$ Ibrahim Elfiky, Terapi Berpikir Positif, (Jakarta: Penerbit Zaman, 2011), hlm. 205

${ }^{6}$ Wenny Aidina, Haiyun Nisa, dkk, Hubungan Antara Penerimaan Diri dengan Optimisme Menghadapi Masa Depan Pada Remaja di Panti Asuhan, Jurnal Psikohumanika, Vol. VI No. 2 2013, diakses https://www.researchgate.net/ pada tanggal 28 April 2020, hlm. 2 
mental yang baik akan terefleksi dari tindakan dan perbuatan yang baik. $^{7}$

Sikap optimis dapat ditunjukan dengan adanya sikap yang tidak mudah menyerah dalam menghadapi kehidupan, selalu mempunyai harapan yang baik, serta selalu berpikir positif dan realistis dalam menghadapi setiap persoalan. Perasaan optimis membawa individu kepada keyakinan terhadap keberhasilan serta percaya pada diri sendiri dengan kemampuan yang dimiliki. Optimisme merupakan keyakinan yang dimiliki seseorang bahwa sesuatu yang baik akan terjadi dimasa depan dan menyebabkan seseorang mempunyai harapan bahwa dengan semangat dan kerja keras keinginan akan tercapai dan optimisme merupakan kekuatan psikologis seseorang dalam mencapai masa depannya. ${ }^{8}$

Optimis merupakan keyakinan individu dalam mengubah sesuatu kearah yang lebih baik, memiliki harapan dan kepercayaan terhadap masa depan. Seseorang yang mepunyai sikap optimis lebih memperlihatkan bahwa fisiknya sehat, yakni tidak mudah depresi, tidak mudah stress, lebih produktif, dan selalu memiliki harapan untuk mengontrol setiap proses mental yang dimilikinya. Individu yang optimis ditengah pandemi Covid-19 ini akan muncul kehidupan baru yang lebih baik. Dengan rasa optimis yang dimiliki, individu mampu memegang kendali atas peristiwa yang dihadapi dan setiap permaslahan yang akan diselesaikan.

Dalam pandangan agama orang yang memiliki mental yang baik adalah orang yang memiliki akidah dan syari'at yang baik. Orang yang bertaqwa adalah orang yang selalu berpikir positif, yakni selalu yakin dengan janji Allah. Apapun yang terjadi akan berakhir dengan baik. Dari cara berpikir seperti ini akan menimbulkan sikap optimisme. Sikap optimis selalu terbukti membuang segala bentuk

${ }^{7}$ Yatama El-Fikri AA, Raih Sukses dengan Senyum dan Optimis, (Jakarta: Elex Media Komputindo, 2011), hlm. 196

8 SH Prayitno, Hubungan Optimisme Masa Depan Dan Motivasi Berprestasi Terhadap Prestasi Belajar Mata Ajar Bahasa Inggris, Jurnal Insight Vol. 13, No. 2 2017, diakses http://jurnal.unmuhjember.ac.id/ pada tanggal 28 April 2020, 31 
ketakutan, kegelisahan yang mengakibatkan seseorang berpikir negatif.

Hasil riset para imuwan menunjukkan bahwa seseorang yang optimis akan lebih sehat dan panjang umur dibanding orang yang pesimis. Para peneliti memperhatikan seseorang yang optimis lebih sanggup menghadapi stress dan kemungkinan kecil untuk depresi. Berikut ini beberapa manfaat dari sikap optimis antara lain:

a. Orang optimis beresiko kecil terkena serangan jantung. Orang yang mempunyai sikap optimis dan semangat yang positif akan membentuk perasaan yang sangat baik untuk kesehatan jantung.

b. Orang optimis akan lebih bahagia dan lebih sedikit mengalami stress. Orang yang berpikir positif akan lebih percaya diri dan lebih berani mengambil berbagai peluang. Mereka tidak mudah menyerah dan berputus asa.

c. Orang optimis akan lebih sehat dan panjang umur. Kadar hormon stress pada orang optimis akan lebih sedikit sehingga menguatkan sistem imun tubuh dan akan lebih kuat.

d. Orang optimis akan lebih sukses dan berprestasi serta mereka yang optimis selalu memiliki semangat untuk maju.

e. Optimisme bersifat menyembuhkan. Pada studi kesehatan yang dilakukan pada beberapa pasien depresi ditemukan bahwa terapi pikiran positif seperti optimisme ternyata lebih berkhasiat dan efektif memperbaiki kondisi pasien daripada obat-obatan. ${ }^{9}$

Melihat pandemi covid-19 ini, sikap optimis mempunyai andil yang besar untuk melenyapkan serangan Covid-19 disamping menjaga imunitas tubuh dan pola makan yang sehat. Sikap optimis akan meningkatkan imunitas tubuh sehingga kemungkinan terkena virus corona akan rendah. Sikap optimis akan menjaga dan meningkatkan imunitas semakin naik. Namun, jika stress maka akan berpengaruh juga pada imunitas. Sehingga demikian masyarakat diminta untuk menjaga pola pikir yang positif salah satunya yakni

${ }^{9}$ Safruddin et al, Pengembangan Kepribadian dan Profesionalisme Bidan, (Malang: Wineka Media, 2018), hlm. 97 
optimis dan peduli atau tidak egois. Namun tentu saja hal ini harus diimbangi pula dengan mengikuti anjuran pemerintah seperti sosial distancing, menghindari keramaian, bekerja dari rumah, beribadah dirumah dan himbauan dari pemerintah lainnya.

Jadi, dapat penulis simpulkan bahwa sikap optimis adalah salah satu sikap yang terlahir dari pikiran positif, yang menyebabkan energi positif muncul. Sikap positif akan menyebabkan sistem imun seseorang menjadi kuat begitu juga sebaliknya berpikir negative akan menyebabkan sistem imun menjadi lemah.

\section{Masa Pandemi}

Dalam Bahasa Yunani Suatu Pandemi berasal dari kata "pan" yang mempunyai arti semua dan "demos" yang artinya rakyat atau epidemic/wabah global yang merupakan terjadinya fenomena penyakit menular pada banyak orang dalam daerah geografi yang luas. Dikatakan wabah semacam ini dalam waktu singkat dan dapat menyebar dan meluas lintas negara.

Menurut Scott dan Duncan mengatakan pandemi adalah suatu bentuk penyakit menular yang dicirikan sebagai wabah hemoragik yang mirip dengan ebola. Pandemic menunjukkan bahwa luas dan gejalanya dapat dijelaskan dengan kombinasi penyakit pes dengan penyaki lain termasuk tipus, cacar, dan saluran infeksi pernapasan.

Pandemi adalah menyebarkan penyakit dari orang ke orang dengan sangat pesat. Pandemi didefinisikan sebagai epidemik yang terjadi disemua daerah didunia, ataupun ditempat yang luas melintasi batas negara. Sesuatu dikatakan pandemi apabila menyebarkan penyakit dengan jumlah yang besar meliputi imunitas populasi, virologi, maupun keparahan penyakit didunia. ${ }^{10}$

Menurut organisasi kesehatan dunia (WHO), suatu fenomena dapat dikatakan pandemi apabila ketiga syarat berikut telah terpenuhi, diantaranya:

a. Timbulnya penyakit baru pada suatu populasi.

${ }^{10}$ Masrul et al, Pandemik Covid-19, (Jakarta: Yayasan Kita Menulis, 2020), hlm. 9 
b. Agen penyebab penyakit menginfeksi manusia dan menyebabkan sakit serius

c. Agen penyebab penyakit menyebar dengan mudah dan berkelanjutan pada manusia. ${ }^{11}$

Periode pandemi adalah periode dimana terjadi penularan antarmanusia dan sudah melampaui berbagai Negara. ${ }^{12}$ Suatu keadaan atau fenomena tidak dapat dikatakan sebagai pandemi hanya karena menewaskan banyak orang. Sebagai contoh, kelas penyakit yang dikenal sebagai kanker menimbulkan angka kematian yang tinggi namun tidak digolongkan sebagai pandemi karena tidak ditularkan.

Jadi dapat penulis simpulkan masa pandemi adalah masa dimana suatu penularan yang terjadi pada antarmanusia di wilayah yang luas.

\section{Covid-19}

Corona virus adalah sekumpulan virus dari subfamily Orthocoronavirinae dalam keluarga Coronaviridae dan Ordo Nidovirales. Kelompok virus ini yang dapat menyebabkan penyakit pada burung dan mamalia termasuk manusia. ${ }^{13}$

Virus corona dalam Bahasa latin berarti mahkota. Dinamakan corona karena bentuknya yang seperti kapsul, tidak bersegmen, dan dikelilingi protein yang disekelilingnya yang seperti mahkota. Virus corona tersusun dari RNA yang membawa materi genetik. Virus corona menempel ditubuh makhluk hidup dengan menempelkan membran tubuhnya ke dinding sel inang. Didalam sel inang virus akan mereplikasi tubuhnya sehingga mampu menginfeksi tubuh-tubuh lainnya, ${ }^{14}$

11 Tamher \& Noorkasiani, Flu Burung: Aspek Klinis dan Epidemiologis, (Jakarta: Salemba Medika, 2010), hlm. 34

${ }^{12}$ Sitepoe Mangku, Melawan Influenza A (H1N1), (Jakarta: Gramedia widiasarana Indonesia, 2011), hlm. 29

${ }^{13}$ M Alief Ibadurrahman, Corona Virus, (Bekasi: MAI, 2020), hlm. 13

${ }^{14}$ Pradipta Jaka \& N A Muslim, Buku Panduan Virus Corona, (Jakarta: Elex Media Komputindo, 2020), hlm. 7 
Virus corona merupakan sebuah virus yang ditemukan pada manusia dan hewan, sebagian besar virusnya dapat menginfeksi manusia serta dapat menyebabkan berbagai penyakit umum seperti flu hingga penyakit yang lebih fatal seperti middle East Respiratory Syndrome (Mers) dan Severe Acute Respiratory Syndrome (SARS). ${ }^{15}$

Menurut buku pedoman Polri Menghadapi Covid-19, virus corona adalah kumpulan virus yang bisa menginfeksi sistem pernapasan. Gejala dari virus ini adalah infeksi pernapasan ringan, seperti flu. Virus corona ini jga bisa menyebabkan infeksi pernapasan berat seperti pneumonia. Virus corona dapat dengan cepat menular dan menyebar diberbagai wilayah.

Virus corona ditemukan pada 1960 dirongga hidung pasien dengan pilek. Organisme ini diyakini bertanggung jawab untuk sebagian besar dari semua pilek. ${ }^{16}$ Pada umumnya virus corona menyebabkan infeksi saluran pernapasan ringan pada manusia. Korona virus menyebabkan pilek dengan gejala utama seperti demam dan sakit tenggorokan akibat pembengkakan adenoid, terutama pada musim dingin dan awal musim semi. Korona virus dapat menyebabkan pneumonia baik langsung maupun sekunder, dan dapat menyebabkan bronchitis baik langsung maupun sekunder.

Pandemi covid-19 perlu menjadi perhatian orang yang memiliki riwayat penyakit mendasar, terutama penyakit jantung. Para pakar kesehatan telah memperingatkan orang dengan penyakit jantung harus ekstra waspada. Wabah virus ini bukan hanya soal angka, semua orang perlu tau bahaya virus coron dan efeknya pada orang dengan penyakit bawaan. ${ }^{17}$

Pandemi Covid-19 mempunyai 3 dampak utama antara lain:

a. Fisik (dari virus itu sendiri)

b. Psikis/Mental (akibat pemberitahuan/kabar yang beredar)

${ }^{15}$ Faizin K Ahmad, Effendi David, Membaca Corona Essai-essai tentang manusia, wabah, dan dunia, (Gresik: Caremedia Communication, 2020), hlm. 110

${ }^{16}$ Bruno DM, Coronavirus, (Del Medico Bruno, 2020), hlm. 35

${ }^{17}$ M Alief Ibadurrahman, Corona Virus, (Bekasi: MAI, 2020), hlm. 14 
c. Ekonomi. ${ }^{18}$

Selain dari dampak tersebut, ada dampak lain yakni yang berhubungan dengan pembelajaran. Dampak tersebut antara lain yaitu berapa dampak yang dirasakan murid pada proses belajar mengajar di rumah. Para murid merasa dipaksa belajar jarak jauh dengan sarana dan prasarana yang kurang memadai dirumah. Dampak selanjutnya yang dialami murid yaitu sekolah diliburkan terlalu lama membuat anak-anak jenuh.

Tidak hanya murid saja. Namun dampak covid-19 ini juga dirasakan oleh orang tua dan guru. Pasalnya para orang tua disuguhkan adanya penambahan biaya pembelian kuota internet bertambah, teknologi online memerlukan koneksi jaringan ke internet dan akan menambah beban pengeluaran orang tua. Dampak yang dirasakan guru yaitu tidak semua guru mahir menggunakan teknologi internet atau media sosial sebagai sarana pembelajaran, ada beberapa guru senior belum mampu sepenuhnya menggunakan media elektronik untuk penunjang kegiatan pembelajaran online dan perlu pendampingan dan pelatihan terlebih dahulu. Dan kompetensi guru dalam menggunakan teknologi akan mempengaruhi kualitas program belajar mengajar oleh karena itu sebelum diadakan program belajar online para guru wajib untuk diberikan pelatihan terlebih dahulu. ${ }^{19}$

\section{Sikap Positif dimasa Covid-19}

Penduduk Indonesia adalah, penduduk terbanyak dibelakang China, India, dan Amerika Serikat. Dari sisi kedisiplinan harus diakui bahwa kesadaran masyarakat Indonesia masih sangat rendah, sementara dari sisi kekuatan ekonomi Indonesia juga tidak bisa dibilang kuat. Berbagai faktor ini menjadi kendala besar dimana opsi seperti lockdown yang dilakukan oleh berbagai negara tidak akan berjalan baik diIndonesia. Jika lockdown diberlakukan akan terjadi banyak sekali ketidakstabilan, baik dari sisi moral dan sosial.

${ }^{18}$ Gandrung CS, Melawan Virus Corona Covid-19 Dengan Kekuatan Mental dan Pikiran, (Jakarta: Serambi buku, 2020), hlm. 3

${ }^{19}$ Agus P, Rudi P, dkk, Studi Eksploratif Dampak Pandemi COVID-19 Terhadap Proses Pembelajaran Online di Sekolah Dasar, Journal Of Education, Phsycologi, dan Counselling, Vol. 02, No. 01, 2020, diakses https://www.researchgate.net/ pada tanggal 28 April 2020, 8 
Masyarakat dan para pekerja yang berpenghasilan menengah kebawah akan merasa keberatan dan sangat terpukul jika lockdown diberlakukan. Dampak adanya virus ini pun sangat berat yakni fisik yaitu efek dari virus itu sendiri, psikis/mental dari pemberitaan atau kabar yang beredar, dan yang paling miris yaitu ekonomi.

Akibat dari Covid-19 ini banyak pemikiran yang diajukan sebagai upaya untuk melawan pandemi Covid-19 di Indonesia, lockdown total, lockdown sebagian, pengobatan, pencegahan, dan lain sebagainya. Dengan sikap yang takut akan segala ancaman dan keresahan, akal akan mengeluarkan hormon stress dan mematikan imunitas tubuh atau bisa disebut Shutdown the Immune System, yang pada akhirnya tidak bisa melawan virus corona.

Ditengah kegalauan menghadapi Covid-19 di Negeri ini berbagai himbauan dari pemerintah dalam menghadang pandemi Covid-19 ini yaitu mencuci tangan dengan sabun, memakai handsanitizer atau antiseptik ketika hendak keluar, memakai masker, menyemprotkan disinfektan, menghindari kerumunan massa, menjaga jarak dengan orang lain, belajar dirumah, beribadah dirumah, dan himbauan lainnya yang harus kita patuhi.

Selain himbauan dari pemerintah ada energi besar yang dapat dibangun yaitu sikap optimis. Sikap optimis dalam menghadapi pandemi Covid-19 ini harus dibangun. Layaknya Covid-19 yang mudah tersebar, sikap optimis juga harus mudah tersebar dan merasuki jiwa-jiwa anak bangsa, hingga tumbuh keyakinan kuat untuk bisa berdiri tegak menghadapi pandemi Covid-19.

Sebagai seorang mukmin tentunya panutan kita adalah nabi Muhammad saw. sebagai uswatun khasanah. Ketika ada himbauan dari pemerintah seperti physical distancing, social distancing, dan lain sebagainya, semua adalah akhlak seorang mukmin dalam menghadapi Covid-19. Pertahanan untuk menghadapi Covid19sendiri adalah imun masing-masing dari individu. Karenanya, imun setiap individu harus kuat. Cara agar imun tetap kuat adalah makan makanan yang halal, istirahat yang cukup, menjaga kebersihan, menjaga fisik dan mental, dan tidak lupa untuk berpikir positif, yaitu 
yakin atau optimis bahwa masyarakat Indonesia mampu menghadapi Covid-19 dengan tenang tidak gegabah.

Seperti ajaran Rasulullah saw. Ketika tertimpa musibah wabah yaitu tetap membangun pikiran yang positif, prasangka baik, optimis, ikhtiar serta tawakkal. Rasulullah saw. bersabda "tidaklah Allah SWT menurunkan suatu penyakit, kecuali Dia juga yang menurunkan penawarnya". (HR. Bukhori). Rasulullah saw. sangat mengantisipasi penularan penyakit, Rasulullah juga telah menemukan, memerintahkan, dan melaksanakan sistem karantina. ${ }^{20}$

Wabah Covid-19 ini tak lain hanyalah teguran dari Allah SWT sekaligus rahmat agar manusia tetap ingat kekuasaan Allah yang tiada bandingannya. Berprasangka baik, berpikir positif serta mempunyai sikap optimis dengan kasih sayang-Nya Allah akan segera mencabut cobaan ini dalam waktu yang tidak lama. Tetap mematuhi himbauan dari pemerintah dan optimis untuk menghadapi pandemi Covid-19.

\section{SIMPULAN}

Sikap optimis adalah salah satu sikap yang terlahir dari pikiran positif, yang menyebabkan energi positif muncul. Sikap positif akan menyebabkan sistem imun seseorang menjadi kuat begitu juga sebaliknya berpikir negatif akan menyebabkan sistem imun menjadi lemah. Ditengah kegalauan menghadapi Covid-19 di Negeri ini berbagai himbauan dari pemerintah dalam menghadang pandemi Covid-19 ini harus kita patuhi. Berprasangka baik, berpikir positif serta mempunyai sikap optimis dengan kasih sayang-Nya Allah akan segera mencabut cobaan ini dalam waktu yang tidak lama. Tetap mematuhi himbauan dari pemerintah dan optimis untuk menghadapi pandemi Covid-19.

\section{DAFTAR PUSTAKA}

Aidina, W., Nisa, H., \& Sulistyani, A. (2013). Hubungan Antara Penerimaan Diri dengan Optimisme Menghadapi Masa Depan Pada Remaja di Panti Asuhan. Jurnal Psikohumanika, 6(2), 2. Elfiky, I. (2011). Terapi Berpikir Positif. Penerbit Zaman.

${ }^{20}$ M Abdul Basith, Cara Nabi Mencegah Penyakit, (Jakarta: Serambi, 2010), hlm. 13 
Fikri, A. A. Y. El. (2011). Raih Sukses dengan Senyum dan Optimis. Elex Media Komputindo.

Hasan, M. (2015). Nilai-nilai Pendidikan Islam dalam Maulid Nabi Muhammad SAW. Al-Insyiroh: Jurnal Studi Keislaman, 1(1), 180213.

Ide, P. (2010). Imunisasi Mental untuk Bangkitkan Optimisme. Elex Media Komputindo.

Karimi, A. F., \& Efendi, D. (2020). Membaca Corona Essai-essai tentang manusia, wabah, dan dunia. Caremedia Communication.

M Alief Ibadurrahman. (2020). Corona Virus. MAI.

Masrul, Abdillah, L. A., \& Tasnim. (2020). Pandemik Covid-19. Yayasan Kita Menulis.

Mastuti, R., Maulana, S., \& Iqbal, M. (2020). Teaching from Home. Yayasan Kita Menulis.

Medico, B. Del. (2020). Coronavirus. Del Medico Bruno.

Mufaizin, M. (2018). Kearifan Syariat dan Hikmah dalam Puasa. AlInsyiroh: Jurnal Studi Keislaman, 2(1), 103-127.

Nurkidam, \& Qodarudin, M. (2020). Coronalogy. IAIN Parepare.

Polri, M. (2020). Buku Pedoman Polri Menghadapi Covid-19. Mabes Polri.

Pradipta, J., \& Nazaruddin, A. M. (2020). Buku Panduan Virus Corona. Elex Media Komputindo.

Prayitno, S. H., \& Ayu, S. M. (2017). Hubungan Optimisme Masa Depan Dan Motivasi Berprestasi Terhadap Prestasi Belajar Mata Ajar Bahasa Inggris Mahasiswa Semester 1 Prodi Diii Keperawatan Rustida Tahun Ajaran 2016-2017. Jurnal Insight Fakultas Psikologi Universitas Muhammadiyah Jember, 13(2), 31.

Purwanto, A., Pramono, R., Asbari, M., Santoso, P. B., Mayesti, L., Wijayanti, Hyun, C. C., \& Putri, R. S. (2020). Studi Eksploratif Dampak Pandemi COVID-19 Terhadap Proses Pembelajaran Online di Sekolah Dasar. Journal Of Education, Pshicology and Counseling, 2(1), 8 .

Safrudin, Mulyati, S., \& Lubis, R. (2018). Pengembangan Kepribadian dan Profesionalisme Bidan. Wineka Media.

Sayyid, A. B. M. (2010). Cara Nabi Mencegah Penyakit. Serambi buku.

Sitepoe, M. (2011). Melawan Influenza A (H1N1). Gramedia widiasarana 
Indonesia.

Sono, G. C. (2020). Melawan Virus Corona Covid-19 Dengan Kekuatan Mental dan Pikiran. Serambi buku.

Tamher, S., \& Noorkasiani. (2010). Flu Burung: Aspek Klinis dan Epidemiologis. Salemba Medika.

Tobias, L. (2007). Homoseksualitas di Eropa Abad Pertengahan. Combridge Stanford Books.

Wahyudi, I. (2011). Rahasia Menjadi Kaya Sejak Dini. Elex Media Komputindo. 